\title{
The Psycholinguistic Background of L1 Polish Students of L3 Spanish
}

\begin{abstract}
The study was aimed at exploring the psycholinguistic background of Polish students of L3 Spanish. Two groups of students (B1 and B2) were asked to fill out a survey with questions related to proficiency, self-confidence, language identity, usefulness, prestige, stress, sound, and frequency of use. The last part of the survey included some questions about psychotypology, as well. In terms of foreign language anxiety, Spanish was ranked by most of the students as the most stressful language. A follow-up session was carried out with them in order to try to discuss the reasons behind their choices, and their feedback helped to shed some light on the topic and raised further questions about the role and impact of Polish teachers of Spanish in Poland.
\end{abstract}

Keywords: sociolinguistics, stress, foreign language anxiety, L3 Spanish, third language acquisition, multilingualism, psychotypology.

\section{Introduction}

The following study was aimed at exploring the psycholinguistic background of Polish students of L3 Spanish from a multilingual point of view. That is why, the study begins with a short summary of the the situation of English both in Europe and, more precisely, in Poland in order to give a general picture of the linguistic situation in which the participants of this study grew up. The next section deals with the impact of positive attitudes on language learning and a short review of Dewaele's (2010) findings in terms of foreign language anxiety (FLA). Our study consisted of two groups who had to fill out a survey (see Appendix) with questions related to proficiency, selfconfidence, language identity, usefulness, prestige, stress, sound, and frequency of use. Furthermore, the last part of the survey included some questions about psychotypology, i.e. the perception of linguistic distance between languages.

The study was motivated, in the first place, by many observations with regard to the way Polish students seemed to relate to the languages they studied: Before carrying out this study, we were pretty much convinced (especially after Poland's joining the EU in 2004) that English had become an increasingly "stressful" language, basically because it is mostly associated with work, business, and obligations. On the other hand, Spanish seemed to be mostly associated with holidays, leisure time, and fun. That is why it was surprising when Spanish was ranked by most of the students as 
the most stressful language; because of that a short interview session was carried out with the participants in order to discuss what it was that they found stressful about (learning) Spanish.

\section{The status of English in Europe and in Poland}

Many authors have explored the impact of English as a lingua franca, both in Europe (e.g. Cenoz \& Jessner 2000; James 2000; Jessner 2006; Otwinowska 2016; Ringbom 2007) as in the rest of the world (e.g. Cenoz et al. 2001; Hoffman 2000; Jessner 2006) and several authors (e.g. Hoffman 2000) have already started to talk about (language) identity with English. Aronin \& Singleton (2008: 4) put it quite clearly: "a patterned regularity is discernible in the fact that multilingualism is spreading to all parts of the world, that English has become a world lingua franca and that language use is diversifying". Although neither bilinguism nor multilingualism are new phenomena by any means, Hoffman (2000) argues that this type of bilingualism is indeed something new in the way that "being proficient in English does not mean that one has to be bicultural: (...) there is no need to develop feelings of dual identity and shared loyalties. In this, too, the European bilingual with English differs from members of bilingual families or communities"' (p. 20). This seems to prove quite true for most European countries and, since Poland's joining the European Union in 2004, bilingualism with English seems to be gaining ground all across the country, both in big and small cities, in the academy and on the streets, in upper, middle and lower classes.

However, in contrast to most European countries, Poland is characterized for being a strikingly monolingual country (Kucharczyk 2018; Otwinowska 2016) and, as Otwinowska (2016: xi) points out, "this monolingualism often shapes the way languages are viewed and taught in Poland"2. Kucharczyk (2018: 44) suggests that most of the contact Poles have with an L2 or L3 takes place at school while, on a daily basis, Polish language learners are not surrounded by neither cultural nor linguistic diversity. Although this may be true in most cases, it is also true that most Poles are able to understand at least basic English words or sentences, to a certain extent. The impact of music and movies in English, as well as the use of English for working purposes and also to communicate with speakers from both English-speaking and other European countries has clearly influenced the linguistic landscape in post-2004 Poland. When one walks the streets of Warsaw, one can easily observe how Poles talk to other Poles in Polish but almost immediately switch to English whenever they find out that their interlocutor is not Polish; this may be in part because of their will to practise their English, but also because of the long-held myth that foreigners "do not speak nor understand Polish".

Although true that, in Otwinowska's words (2016: 26), "during the Communist period, English symbolised freedom and modernity to Poles, and since 1989 it has quickly become the most prestigious foreign language across the society", most of the students who took part in our survey

1 For a deeper analysis of the position of English in Europe, see Jessner (2006: 5).

2 For a detailed account of Poland's linguistic history, see Otwinowska (2016: 24-28) and Kucharczyk (forthcoming). 
were born in the early 1990s and have experienced (during the 2010s) a less emotional and more functional rapport with the English language:

Global English identity will thus be related to instrumental aspects of English language use, i.e. the Oughtto $L 2$ self, as opposed to the Ideal L2 Self, related to hopes, aspirations and needs. More people learn English because of the attributes they ought to possess in their professional lives, developing their Oughtto English selves. Therefore, English connected with the 'global English identity' becomes a survival skill of purely utilitarian, or functional nature (Otwinowska 2016: 23-24).

That is why it had been hypothesized in the first place that English was changing its status in Poland from that of the language of freedom and modernity to one of obligations and stress.

\section{The impact of positive attitudes}

There is growing agreement among researchers about the importance of emotion as a very important factor which can play a decisive role in language learning and, more specifically, in language performance. In Dewaele's words (2010: 21):

Emotion is thus at the basis of any learning, or absence of learning. When a stimulus is positively assessed in a learning situation, it will have a positive effect on the amount of attention and effort a learner will be prepared to devote to it. It will also encourage the learner to approach similar stimuli in the future. However, when a stimulus is negatively assessed in a learning situation, less attention and effort will be devoted to it, and negative affective assessment may promote avoidance in the future. (...)

Table 1. FLA when speaking in public (adapted from Dewaele 2010).

\begin{tabular}{|l|c|l|l|l|l|}
\hline Variable & & Level of FLA & Variable & & Level of FLA \\
\hline Chronology & + & $\begin{array}{l}\text { L5 } \\
\text { L4 } \\
\text { L3 } \\
\text { L2 } \\
\text { L1 }\end{array}$ & $\begin{array}{l}\text { Network of } \\
\text { interlocutors }\end{array}$ & + & $\begin{array}{l}\text { Strangers } \\
\text { Colleagues } \\
\text { All } \\
\text { Friends } \\
\text { Family }\end{array}$ \\
\hline $\begin{array}{l}\text { Age of onset of } \\
\text { acquisition }\end{array}$ & + & $\begin{array}{l}18+ \\
13-18\end{array}$ & $\begin{array}{l}\text { Total } \\
\text { language } \\
\text { knowledge } \\
3-2\end{array}$ & + & $\begin{array}{l}\text { Bilinguals } \\
\text { Trilinguals } \\
\text { Quadrilinguals } \\
\text { Pentalinguals }\end{array}$ \\
\hline $\begin{array}{l}\text { Context of } \\
\text { acquisition }\end{array}$ & + & $\begin{array}{l}\text { Instructed } \\
\text { Naturalistic } \\
\text { Mixed }\end{array}$ & $\begin{array}{l}\text { Trait } \\
\text { Emotional } \\
\text { Intelligence }\end{array}$ & - & $\begin{array}{l}\text { Ledium TEI } \\
\text { High TEI }\end{array}$ \\
\hline
\end{tabular}




\begin{tabular}{|l|l|l|l|l|l|}
\hline Variable & & Level of FLA & Variable & & $\begin{array}{l}\text { Level of FLA } \\
\text { Frequency of }\end{array}$ \\
\hline $\begin{array}{l}\text { use } \\
\text { Socialisation } \\
\text { in the FL }\end{array}$ & + & $\begin{array}{l}\text { Yearly or less } \\
\text { Monthly } \\
\text { Weekly } \\
\text { Daily } \\
\text { All day }\end{array}$ & Age & $+\begin{array}{l}\text { Twenties } \\
\text { Teenagers } \\
\text { Thirties } \\
\text { Fourties } \\
\text { Fifties } \\
\text { Sixties }+\end{array}$ \\
\hline
\end{tabular}

A good classroom atmosphere might enhance students' desire to create and preserve these particular social affiliations. On the other hand, a bad atmosphere might be interpreted by students as threatening and might push them toward ending their membership of that classroom community.

In his book Emotions in multiple languages, Dewaele studied the impact of different variables (i.e. chronology, age of onset of acquisition, context of acquisition, frequency of use, socialisation in the FL, network of interlocutors, total language knowledge, trait emotional intelligence, age and education) on foreign language anxiety (see Table 1). He found that among the most stressed are speakers in their twenties of a lately acquired FL (usually after the age of 18), who have learned their FL exclusively in a classroom setting and use it very seldom, who hardly ever use their FL to socialize and use it mostly with strangers, who have a very limited repertoire of languages, low TEI and lack higher education. Dewaele's research mentions students in their twenties, thirties, fourties, fifties and sixties+, but does not include any information about children and adolescents. Wang (2015: 168), on the other hand, commented on the reasons between child-learners being more successful than older learners, arguing that "adolescent-learners have difficulties in participating in language interaction and many of them are reluctant to read aloud and are fearful of failing or looking and sounding foolish. Sometimes, they try to avoid answering questions or communicating with others. These might explain why adolescents (...) are less successful in English learning". On the other hand, children "enjoy taking part in every kind of language activity, and enjoy language interaction. They can speak loudly, they can ask questions anytime, and they are not worried about making mistakes" and all these result "in their enough exposures to L2 and more practice in their speaking and listening skills" (Wang 2015: 168).

The role of the teacher and the impact of the rapport between the students and their teachers was also explored by Mettewie (2004) who found that the rapport between students and their teachers sets the tone for their attitudes toward their FL, especially if the FL is not mainstream, as is the case with Spanish in Poland (cf. Dewaele 2010: 139). Moreover, Poulisse (1997: 63) underlines the benefits of positive interaction in the shape of communicative tasks (e.g. interviews), in which "subjects where able to obtain feedback and help from the interlocutor, and where the 
physical setting and the linguistic context contributed to the clarity of strategies". Kacper \& Kellerman (1997: 5) agree with this view when they say that "the most effective source of input seems to be conversational exchanges in which learners engage - either together with other L2 learners or native speakers - and in which they negotiate (referential) meanings" and, discussing LarsenFreeman and Long (1991), they say that all types of communication strategies "are helpful because they enable learners to keep the conversation going and thereby provide more opportunities for input". According to them, increased stress and less student participation result not only in less output, but also in less input, and would hinder students' attempts at developing a full range of abilities regarding their TL production.

\section{The study}

Although some research has been carried out in terms of cognate recognition and metalinguistic awareness by Polish students (e.g. Otwinowska-Kasztelanic 2011; Otwinowska 2016), the way Polish students relate to the languages within their linguistic repertoire in terms of identification, preferences and beliefs has not been very much explored Moreover, the present study will try to gain some insight on the position of Spanish in the students' linguistic repertoire.

\subsection{Methodology}

In order to explore the students' psycholinguistic background, a survey was created with questions regarding to age, motivation type, hometown, linguistic experience, type and quantity of exposure to the L2 and L3, and psychotypology (see Appendix).

A follow-up session was carried out one week after the participants took part in the survey in order to provide triangulation and thus explore the reasons why they had chosen Spanish as either the most or second most stressful language. A 5-minute interview was carried out individually with each student, in which they were asked to answer the following question: ¿Qué es lo que te estresa con respecto al idioma español? (Eng. 'What do you find most stressful about (learning) Spanish?'). No feedback other than backchanneling cues were provided so as not to interfere with their answers.

\subsection{Study 1: Spanish L3, B1 group}

\subsubsection{Subjects}

The survey was conducted in a Spanish B1 course at the University of Warsaw at the end of the winter semester 2016/2017. 17 Polish students took part in the survey (13 female students and 4 male students); the ages ranged between 19 and 25, with an average of 21.58 years. They were given a total of 40 minutes to complete the task. Before starting the task, we spent about 10 minutes going over the questions in order to make sure that everything was clear and that they knew exactly how to fulfill the task.

9 students claimed to be learning Spanish for personal reasons, 1 student because she had to, while the rest $(\mathrm{N}=7)$ said that they were taking classes for both reasons. As for the students' city 
of origin, 9 were from cities above 400,000 (Warsaw), 5 from towns under 100,000 (Krosno, Pisz, Sędriszów and Bełchatów), 2 came from cities between 100,000-400,000 (Lublin and Płock), and 1 from a village (Cegłów). Students were asked to order all the languages they knew and used in terms of the age they were at the time they started learning them and the results were the following: Polish was the students' L1 $(\mathrm{N}=17)$ and English was their L2 in most of the cases $(\mathrm{N}=13)$ but for 3 students whose L2 was German. Spanish appears as the students' L3 in 6 cases, as their L4 in 10 cases, and as an L5 only in 1 case. Regarding English, the average age of onset was 6.76 years (min. 3, max. 13). As for Spanish, the average age of onset was 18.18 (min. 13, max. 23).

\subsubsection{Psycholinguistic background}

$100 \%$ of the students $(\mathrm{N}=17)$ stated that Polish was the language they felt more comfortable with (their L1), as well as being the language they claimed to know best. In terms of proficiency, their L2 turned out to be English $(\mathrm{N}=14)$, followed by German $(\mathrm{N}=2)$, and Italian $(\mathrm{N}=1)$. Regarding Spanish, it was most students' L3 in terms of competence $(\mathrm{N}=11)$, followed by German $(\mathrm{N}=3)$, English $(\mathrm{N}=1)$, and French $(\mathrm{N}=1)$. Students also spoke (to a lesser degree) Russian $(\mathrm{N}=2)$, Arabic $(\mathrm{N}=1)$, Dutch $(\mathrm{N}=1)$, and Portuguese $(\mathrm{N}=1)$.

Students were later asked about which language they felt more identified with, and which one reflected their personality best. Polish was chosen by most of the students $(\mathrm{N}=13)$, while 2 chose English, 1 Spanish, and 1 Italian. In the second place, English was chosen by 9 students, Polish by 3 , Spanish by 3 , and German by 2 . Spanish prevails only as a third option in 8 cases.

Next, we asked students to order the languages they knew in terms of those which helped them best when it came to expressing their feelings, wishes and fears. Most students chose Polish $(\mathrm{N}=$ 14), but surprisingly 3 students chose English. Once again, Spanish prevails as L3 $(\mathrm{N}=11)$, right after Polish and English.

In terms of usefulness and convenience, English was chosen by most students $(\mathrm{N}=13)$, while only 4 opted for Polish. Spanish prevails as the second most useful language in 9 cases, mostly after English. Among the least useful languages, we found Polish $(\mathrm{N}=7)$.

Regarding the issue of social prestige, English was highly regarded by 13 students, followed by Spanish $(\mathrm{N}=2)$, German $(\mathrm{N}=1)$, and French $(\mathrm{N}=1)$. In most cases, Polish was perceived by the students as the least prestigious language $(\mathrm{N}=15)$.

The point which raised many questions during the survey and which was shocking to us was the question related to stress. Shockingly, Spanish turned out to be the most stressful language among the students $(\mathrm{N}=6)$, closely followed by German $(\mathrm{N}=5)$, and Russian, Arabic, English, Italian, and French with 1 vote each. Moreover, Spanish was also chosen as the second most stressful language in 9 cases, which means that in 15 cases was Spanish chosen among the two most stressful languages. On the other hand, almost everyone $(\mathrm{N}=16)$ chose Polish as the least stressful language, except for 1 student who said that it was actually the most stressful one for her.

Later, students were asked to rank the languages they knew and used in terms of their sound. The best sounding languages turned out to be English $(\mathrm{N}=8)$, closely followed by Spanish $(\mathrm{N}=6)$, 
Polish $(\mathrm{N}=2)$, and Italian $(\mathrm{N}=1)$. Interestingly, Polish was chosen in 8 cases as the worst sounding language, followed by German $(\mathrm{N}=4)$, English $(\mathrm{N}=3)$, Russian $(\mathrm{N}=1)$, and also only 1 student rated Spanish as the worst sounding language.

As expected, Polish turned out to be the language that $88,23 \%$ of the students $(\mathrm{N}=15)$ used most often, while the rest $(\mathrm{N}=2)$ said that it was English. The second most used language was English $(\mathrm{N}=10)$ and, to a lesser degree, Polish $(\mathrm{N}=2)$ and German $(\mathrm{N}=2)$. Then again, Spanish prevailed as L3 in 11 cases.

\subsubsection{Psychotypologies}

The final part of the survey consisted of two sets of questions aimed at evaluating the way in which the students perceived the linguistic distance ( $p$ sychotypology) between the languages that they know and use.

In the first set, the students were asked to say which language, in their opinion, is the closest to Polish, in respect of its different subsystems - vocabulary, phonology, grammar, syntax and morphology. When it comes to vocabulary, Spanish and English turned out to be the most similar to Polish with 4 votes each. 4 students also said that none of the languages they knew was very similar to Polish, while the rest opted for German $(\mathrm{N}=3)$, Russian $(\mathrm{N}=1)$, and Latin $(\mathrm{N}=1)$. Phonologically, Spanish was ranked as the most similar to Polish $(\mathrm{N}=10)$, followed by English $(\mathrm{N}=2)$, None $(\mathrm{N}=2)$, Italian $(\mathrm{N}=1)$, Russian $(\mathrm{N}=1)$, and German $(\mathrm{N}=1)$. Regarding grammar, students also ranked Spanish as being the closest to Polish $(\mathrm{N}=6)$, followed by English $(\mathrm{N}=4)$, None $(\mathrm{N}=4)$, Russian $(\mathrm{N}=1)$, German $(\mathrm{N}=1)$, and Latin $(\mathrm{N}=1)$. As for syntax, Spanish was perceived by the students as being the most similar to Polish $(\mathrm{N}=9)$, followed by None $(\mathrm{N}=4)$, English $(\mathrm{N}=3)$, and Russian $(\mathrm{N}=1)$. Finally, Spanish also ranked first $(\mathrm{N}=6)$ with respect to morphology, closely followed by None $(\mathrm{N}=5)$, English $(\mathrm{N}=4)$, Russian $(\mathrm{N}=1)$, and German $(\mathrm{N}=1)$.

In the second set of questions, the students were asked to say which language (Polish or English), in their opinion, helped them the most in order to learn Spanish, in terms of its different subsystems - vocabulary, phonology, grammar, syntax and morphology. Firstly, English was perceived as being most helpful when it comes to learning Spanish vocabulary $(\mathrm{N}=15)$, followed by Polish $(\mathrm{N}=2)$. However, Polish was perceived as being more similar to Spanish with respect to phonology $(\mathrm{N}=12)$, followed by English $(\mathrm{N}=4)$ and None $(\mathrm{N}=1)$. Most of the students found English to be more similar to Spanish in terms of grammar $(\mathrm{N}=11)$, followed by Polish $(\mathrm{N}=5)$ and None $(\mathrm{N}=1)$. With respect to syntax, 9 students found English to be more helpful in learning Spanish, while 7 of them said Polish was, and 1 student said that none of them. Finally, English ranked first $(\mathrm{N}=10)$ with respect to morphology, followed by Polish $(\mathrm{N}=4)$ and None $(\mathrm{N}=3)$. 


\subsection{Study 2: Spanish L3, B2 group}

\subsubsection{Subjects}

The survey was conducted in a Spanish B2 course at the University of Warsaw at the end of the winter semester 2016/2017. 17 Polish students took part in the survey (16 female students and 1 male student); the ages ranged between 19 and 25, with an average of 21.29. They were given a total of 40 minutes to complete the task. Before starting the task, we spent about 10 minutes going over the questions in order to make sure that everything was clear and that they knew exactly how to fulfill the task.

Regarding motivation (see Table 2), 10 students claimed to be learning Spanish for personal reasons, 1 student because he had to, while the rest $(\mathrm{N}=6)$ said they were taking classes for both reasons. As for the student's city of origin, 10 were from cities above 400,000 (Warsaw), 5 from cities between 100,000-400,000 (Elbląg, Sosnowiec, Bielsko-Biała, Bydgoszcz and Rzeszów), and 2 came from towns under 100,000 (Chełm and Świdnik). Students were asked to order all the languages they knew and used in terms of the age they were at the time they started learning them and the results were the following: Polish was the students' L1 $(\mathrm{N}=17)$ and English was their L2 $(\mathrm{N}=17)$. Spanish appears as the students' L3 in 14 cases and as their L4 in 3 cases. Regarding English, the average age of onset was 5.59 (min. 3, max. 8). As for Spanish, the average age of onset was 15 (min. 12, max. 22).

\subsubsection{Psycholinguistic background}

$100 \%$ of the students $(\mathrm{N}=17)$ stated that Polish was the language they felt more comfortable with (their L1), as well as being the language they claimed to know best. In terms of proficiency, their L2 turned out to be English $(\mathrm{N}=12)$, followed by Spanish $(\mathrm{N}=4)$, and Portuguese $(\mathrm{N}=1)$. Regarding Spanish, it was the students' L3 in most of the cases $(\mathrm{N}=12)$, followed by English $(\mathrm{N}=5)$. Students also spoke (to a lesser degree) German $(\mathrm{N}=5)$, Italian $(\mathrm{N}=1)$, Portuguese $(\mathrm{N}=1)$, Russian $(\mathrm{N}=1)$, Japanese $(\mathrm{N}=1)$, and Mandarin Chinese $(\mathrm{N}=1)$.

Table 2. Comparison of the participants in both groups.

\begin{tabular}{|l|l|l|}
\hline Background & B1 group & B2 group \\
\hline Number of students & 17 & 17 \\
\hline Age & $\begin{array}{l}21.58 \text { y/o. } \\
(\min .19, \max .25)\end{array}$ & $\begin{array}{l}21.29 \text { y/o } \\
(\min .19, \text { max. 25) }\end{array}$ \\
\hline Motivation & $\begin{array}{l}\text { Intrinsic }(\mathrm{N}=9) \\
\text { Both }(\mathrm{N}=7) \\
\text { Extrinsic }(\mathrm{N}=1)\end{array}$ & $\begin{array}{l}\text { Intrinsic }(\mathrm{N}=10) \\
\text { Both }(\mathrm{N}=6) \\
\text { Extrinsic }(\mathrm{N}=1)\end{array}$ \\
\hline
\end{tabular}




\begin{tabular}{|l|l|l|}
\hline Background & B1 group & B2 group \\
\hline City of origin & $\begin{array}{l}400,000+(\mathrm{N}=9) \\
100,000-400,000(\mathrm{~N}=2) \\
\text { under } 100,000(\mathrm{~N}=5) \\
\text { villages }(\mathrm{N}=1)\end{array}$ & $\begin{array}{l}400,000+(\mathrm{N}=10) \\
100,000-400,000(\mathrm{~N}=5) \\
\text { under 100,000 }(\mathrm{N}=2) \\
\text { villages }(\mathrm{N}=0)\end{array}$ \\
\hline Age of onset (English) & $\begin{array}{l}6.76 \mathrm{y} / \mathrm{o} \\
\text { (min. 3, max. 13) }\end{array}$ & $\begin{array}{l}5.59 \mathrm{y} / \mathrm{o} \\
(\min .3, \max .8)\end{array}$ \\
\hline Age of onset (Spanish) & $\begin{array}{l}18.18 \mathrm{y} / \mathrm{o} \\
\text { (min. 13, max. 23) }\end{array}$ & $\begin{array}{l}15 \mathrm{y} / \mathrm{o} \\
(\min .12, \max .22) .\end{array}$ \\
\hline
\end{tabular}

Students were later asked about which language they felt more identified with, and which one reflected their personality best. As we expected, Polish was chosen by 15 students and only 2 chose English. In the second place, English was chosen by 9 students and Spanish by 6 . Spanish prevails only as a third option in 11 cases.

Next, we asked students to order the languages they knew in terms of those which helped them best when it came to expressing their feelings, wishes and fears. Practically everyone chose Polish $(\mathrm{N}=16)$, while only 1 student chose English. Once again, Spanish prevails as L3 $(\mathrm{N}=13)$, right after Polish and English.

In terms of usefulness and convenience, the results were tight between English $(\mathrm{N}=9)$ and Polish $(\mathrm{N}=8)$. Spanish appears only both as a second option in 8 cases and as a third option in 8 other cases, just after English and Polish.

Regarding the issue of social prestige, English was highly regarded by 13 students, followed by Spanish and Polish with 2 votes each. As for Spanish, it was chosen 11 times as the second most prestigious language. What was interesting was the fact that Polish was placed last in 14 cases in other words, $82.35 \%$ of the students chose Polish as the least prestigious language among the ones they know.

Table 3. Psycholinguistic background (\%)

\begin{tabular}{|l|l|l|l|l|l|}
\hline $\begin{array}{l}\text { Psycholinguistic } \\
\text { background }\end{array}$ & B1 group & N & $\begin{array}{l}\text { Psycholinguistic } \\
\text { background }\end{array}$ & B2 group & N \\
\hline Proficiency & Polish & 17 & Proficiency & Polish & 17 \\
\hline Language identity & $\begin{array}{l}\text { Polish } \\
\text { English } \\
\text { Spanish } \\
\text { Italian }\end{array}$ & $\begin{array}{l}13 \\
1\end{array}$ & Language identity & $\begin{array}{l}\text { Polish } \\
\text { English }\end{array}$ & $\begin{array}{l}15 \\
2\end{array}$ \\
\hline
\end{tabular}




\begin{tabular}{|c|c|c|c|c|c|}
\hline $\begin{array}{l}\text { Psycholinguistic } \\
\text { background }\end{array}$ & B1 group & $\mathrm{N}$ & $\begin{array}{l}\text { Psycholinguistic } \\
\text { background }\end{array}$ & B2 group & $\mathrm{N}$ \\
\hline Expressiveness & $\begin{array}{l}\text { Polish } \\
\text { English }\end{array}$ & $\begin{array}{l}14 \\
3\end{array}$ & Expressiveness & $\begin{array}{l}\text { Polish } \\
\text { English }\end{array}$ & $\begin{array}{l}16 \\
1\end{array}$ \\
\hline Usefulness & $\begin{array}{l}\text { English } \\
\text { Polish }\end{array}$ & $\begin{array}{l}13 \\
4\end{array}$ & Usefulness & $\begin{array}{l}\text { English } \\
\text { Polish }\end{array}$ & $\begin{array}{l}9 \\
8\end{array}$ \\
\hline Prestige & $\begin{array}{l}\text { English } \\
\text { Spanish } \\
\text { German } \\
\text { French }\end{array}$ & $\begin{array}{l}13 \\
2 \\
1 \\
1\end{array}$ & Prestige & $\begin{array}{l}\text { English } \\
\text { Spanish } \\
\text { Polish }\end{array}$ & $\begin{array}{l}13 \\
2 \\
2\end{array}$ \\
\hline Stress & $\begin{array}{l}\text { Spanish } \\
\text { German } \\
\text { Russian } \\
\text { Arabic } \\
\text { English } \\
\text { Italian } \\
\text { French }\end{array}$ & $\begin{array}{l}6 \\
5 \\
1 \\
1 \\
1 \\
1 \\
1\end{array}$ & Stress & $\begin{array}{l}\text { Spanish } \\
\text { German } \\
\text { English } \\
\text { Polish } \\
\text { Italian } \\
\text { Japanese } \\
\text { Chinese }\end{array}$ & $\begin{array}{l}6 \\
4 \\
2 \\
2 \\
1 \\
1 \\
1\end{array}$ \\
\hline Best sounding & $\begin{array}{l}\text { English } \\
\text { Spanish } \\
\text { Polish } \\
\text { Italian }\end{array}$ & $\begin{array}{l}8 \\
6 \\
2 \\
1\end{array}$ & Best sounding & $\begin{array}{l}\text { Polish } \\
\text { Spanish } \\
\text { English } \\
\text { Portuguese }\end{array}$ & $\begin{array}{l}6 \\
6 \\
4 \\
1\end{array}$ \\
\hline Used most often & $\begin{array}{l}\text { Polish } \\
\text { English }\end{array}$ & $\begin{array}{l}15 \\
2\end{array}$ & Used most often & Polish & 17 \\
\hline
\end{tabular}

Just like the results from the B1 group, the point which drew most of our attention during the survey was the one related to stress. Shockingly, Spanish turned out to be the most stressful language $(\mathrm{N}=6)$, followed by German $(\mathrm{N}=4)$, English $(\mathrm{N}=2)$, Polish $(\mathrm{N}=2)$, Italian $(\mathrm{N}=1)$, Japanese $(\mathrm{N}=1)$, and Chinese $(\mathrm{N}=1)$. Moreover, Spanish was also chosen as the second most stressful language in 6 cases, which means that in 12 cases Spanish was chosen as one of the two most stressful languages. On the other hand, Polish was chosen as the least stressful language in all cases $(\mathrm{N}=15)$ but 2 , precisely in those cases where it was chosen as the most stressful one.

Later, students were asked to rank the languages they knew and used in terms of their sound. The best sounding languages turned out to be Polish $(\mathrm{N}=6)$ andSpanish $(\mathrm{N}=6)$, followed by English $(\mathrm{N}=4)$, and Portuguese $(\mathrm{N}=1)$. Interestingly, Polish was chosen $(\mathrm{N}=5)$, along with German $(\mathrm{N}=5)$ and English $(\mathrm{N}=5)$, as the worst sounding languages. No student rated Spanish as the worst sounding language.

As expected, Polish turned out to be the language that the students used most often $(\mathrm{N}=17)$. The second most used language was English $(\mathrm{N}=12)$ and, to a lesser degree, Spanish $(\mathrm{N}=3)$. Then again, Spanish prevailed as L3 in 14 cases. 


\subsubsection{Psychotypologies}

The final part of the survey consisted of two sets of questions aimed at evaluating the way in which the students perceive the linguistic distance (psychotypology) between the languages that they know and use.

In the first set, the students were asked to say which language, in their opinion, is the closest to Polish, in respect of its different subsystems - vocabulary, phonology, grammar, syntax and morphology. When it comes to vocabulary, Spanish turned out to be the most similar to Polish $(\mathrm{N}=7)$, followed by English $(\mathrm{N}=4)$, None $(\mathrm{N}=3)$, German $(\mathrm{N}=1)$, Russian $(\mathrm{N}=1)$, Portuguese $(\mathrm{N}=1)$.

Table 4.Perceived linguistic distance in terms of Polish (\%)

\begin{tabular}{|c|c|c|c|c|c|}
\hline & B1 group & $\mathrm{N}$ & & B2 group & $\mathrm{N}$ \\
\hline Vocabulary & $\begin{array}{l}\text { Spanish } \\
\text { English } \\
\text { None } \\
\text { German } \\
\text { Russian } \\
\text { Latin }\end{array}$ & $\begin{array}{l}4 \\
4 \\
4 \\
3 \\
1 \\
1\end{array}$ & Vocabulary & $\begin{array}{l}\text { Spanish } \\
\text { English } \\
\text { None } \\
\text { German } \\
\text { Russian } \\
\text { Portuguese }\end{array}$ & $\begin{array}{l}7 \\
4 \\
3 \\
1 \\
1 \\
1\end{array}$ \\
\hline Phonology & $\begin{array}{l}\text { Spanish } \\
\text { English } \\
\text { None } \\
\text { Italian } \\
\text { Russian } \\
\text { German }\end{array}$ & $\begin{array}{l}10 \\
2 \\
2 \\
1 \\
1 \\
1\end{array}$ & Phonology & $\begin{array}{l}\text { Spanish } \\
\text { None } \\
\text { English } \\
\text { German } \\
\text { Russian } \\
\text { Japanese } \\
\text { Portuguese }\end{array}$ & $\begin{array}{l}7 \\
5 \\
1 \\
1 \\
1 \\
1 \\
1\end{array}$ \\
\hline Grammar & $\begin{array}{l}\text { Spanish } \\
\text { English } \\
\text { None } \\
\text { German } \\
\text { Russian } \\
\text { Latin }\end{array}$ & $\begin{array}{l}6 \\
4 \\
4 \\
1 \\
1 \\
1\end{array}$ & Grammar & $\begin{array}{l}\text { Spanish } \\
\text { None } \\
\text { English } \\
\text { German }\end{array}$ & $\begin{array}{l}7 \\
5 \\
4 \\
1\end{array}$ \\
\hline Syntax & $\begin{array}{l}\text { Spanish } \\
\text { None } \\
\text { English } \\
\text { Russian }\end{array}$ & $\begin{array}{l}9 \\
4 \\
3 \\
1\end{array}$ & Syntax & $\begin{array}{l}\text { None } \\
\text { Spanish } \\
\text { English } \\
\text { German }\end{array}$ & $\begin{array}{l}6 \\
5 \\
5 \\
1\end{array}$ \\
\hline Morphology & $\begin{array}{l}\text { Spanish } \\
\text { None } \\
\text { English } \\
\text { Russian } \\
\text { German }\end{array}$ & $\begin{array}{l}6 \\
5 \\
4 \\
1 \\
1\end{array}$ & Morphology & $\begin{array}{l}\text { Spanish } \\
\text { None } \\
\text { English } \\
\text { German }\end{array}$ & $\begin{array}{l}7 \\
7 \\
2 \\
1\end{array}$ \\
\hline
\end{tabular}

Phonologically, Spanish was also ranked as the most similar to Polish $(\mathrm{N}=7)$, followed by None $(\mathrm{N}=5)$, English $(\mathrm{N}=1)$, German $(\mathrm{N}=1)$, Russian $(\mathrm{N}=1)$, Japanese $(\mathrm{N}=1)$, and Portuguese $(\mathrm{N}=1)$. 
Regarding grammar, students also ranked Spanish as being the closest to Polish $(\mathrm{N}=7)$, followed by None $(\mathrm{N}=5)$, English $(\mathrm{N}=4)$, and German $(\mathrm{N}=1)$. As for syntax, none of the languages known by the students was perceived as being the most similar to Polish $(\mathrm{N}=6)$, followed by English and Spanish with 5 votes each, and German $(\mathrm{N}=1)$. Finally, Spanish ranked first $(\mathrm{N}=7)$ with respect to morphology, along with None $(\mathrm{N}=7)$, and followed by English $(\mathrm{N}=2)$ and German $(\mathrm{N}=1)$.

Table 5.Perceived linguistic distance in terms of Spanish $(\%)$

\begin{tabular}{|c|c|c|c|c|c|}
\hline & B1 group & $\mathrm{N}$ & & B2 group & $\mathrm{N}$ \\
\hline Vocabulary & $\begin{array}{l}\text { English } \\
\text { Polish }\end{array}$ & $\begin{array}{l}15 \\
2\end{array}$ & Vocabulary & $\begin{array}{l}\text { English } \\
\text { Polish } \\
\text { Both }\end{array}$ & $\begin{array}{l}14 \\
2 \\
1\end{array}$ \\
\hline Phonology & $\begin{array}{l}\text { Polish } \\
\text { English } \\
\text { None }\end{array}$ & $\begin{array}{l}12 \\
4 \\
1\end{array}$ & Phonology & $\begin{array}{l}\text { Polish } \\
\text { English } \\
\text { None }\end{array}$ & $\begin{array}{l}12 \\
4 \\
1\end{array}$ \\
\hline Grammar & $\begin{array}{l}\text { English } \\
\text { Polish } \\
\text { None }\end{array}$ & $\begin{array}{l}11 \\
5 \\
1\end{array}$ & Grammar & $\begin{array}{l}\text { English } \\
\text { Polish } \\
\text { None }\end{array}$ & $\begin{array}{l}14 \\
2 \\
1\end{array}$ \\
\hline Syntax & $\begin{array}{l}\text { English } \\
\text { Polish } \\
\text { None }\end{array}$ & $\begin{array}{l}9 \\
7 \\
1\end{array}$ & Syntax & $\begin{array}{l}\text { English } \\
\text { Polish } \\
\text { None }\end{array}$ & $\begin{array}{l}11 \\
4 \\
2\end{array}$ \\
\hline Morphology & $\begin{array}{l}\text { English } \\
\text { Polish } \\
\text { None }\end{array}$ & $\begin{array}{l}10 \\
4 \\
3\end{array}$ & Morphology & $\begin{array}{l}\text { English } \\
\text { Polish } \\
\text { None }\end{array}$ & $\begin{array}{l}13 \\
2 \\
2\end{array}$ \\
\hline
\end{tabular}

In the second set of questions, the students were asked to say which language (Polish or English), in their opinion, helped them most in learning Spanish, in terms of its different subsystems - vocabulary, phonology, grammar, syntax and morphology. Firstly, English was perceived as being most helpful when it comes to learning Spanish vocabulary $(\mathrm{N}=14)$, followed by Polish $(\mathrm{N}=$ 2) and Both $(\mathrm{N}=1)$. However, Polish was perceived as being more similar to Spanish with respect to phonology $(\mathrm{N}=12)$, followed by English $(\mathrm{N}=4)$ and None $(\mathrm{N}=1)$. Most of the students found English to be more similar to Spanish in terms of grammar $(\mathrm{N}=14)$, followed by Polish $(\mathrm{N}=2)$ and None $(\mathrm{N}=1)$. With respect to syntax, 11 students found English to be more helpful in learning Spanish, while 4 of them said Polish was, and 2 students said that none of them. Finally, English ranked first $(\mathrm{N}=13)$ with respect to morphology, followed by Polish $(\mathrm{N}=2)$ and None $(\mathrm{N}=2)$.

\subsection{Follow-up session}

As for the B1 group, 7 students (S2,S6,S9,S12,S13,S16,S17) did not know or decided not to give any feedback. 
6 students ranked Spanish as being the most stressful language (S1, S2, S7, S9, S10, S14) and suggested the following: S1 said that she found grammar very stressful since there are lots of irregular forms. S7 claimed that the most stressful thing for her was speaking because she did not feel confident about her vocabulary and grammar and she added that she was not able to express as much as she would like to. S10 said that the subjunctive mood was the most difficult thing about Spanish, because he felt he still did not know the rules. S14 claimed that the most stressful thing for her was speaking because she did not do it often and that she felt she mixed Spanish with Italian (note: she had a Spanish speaking boyfriend but with whom she communicated in Italian).

Other 9 students ranked Spanish as the second most stressful language (S3, S4, S5, S6, S8, S11, S12, S15, S16). S3 said he had been learning Spanish for two years, and because of that he did not have a lot of experience (which made him feel insecure), and he felt negative transfer from German to Spanish (although he said that Spanish is more similar to Polish). S4 - one of the strongest students - said that she had started to get confused between Spanish and Italian. She said she had attended a bilingual high school, where she had had both Polish teachers ("more severe... taught only grammar and grammar was the only thing they talked about") and native speakers ("they taught history... but the classes were very natural, we could talk about anything"). S5 stated that speaking was the most stressful thing about learning Spanish and that she felt she did not have enough time to practise. S8 claimed that her level was once better than at present. She added that she knew what she wanted to say but that she did not know how to say it. During high school, she had had native speakers as teachers who provided a very good atmosphere in class. S11 felt his vocabulary was limited. During high school he had had two teachers: one from Uruguay - who provided a very good atmosphere in class - and the other one from Poland. S15 found speaking very stressful, mainly because she didn't feel confident enough. She believed that her level was not very strong. In high school, she had had a Polish teacher of Spanish whose level was "so so", but who created a very positive environment in the classroom.

In the B2 group, 5 students (S18, S25, S28, S29, S32) did not know or decided not to give any feedback.

6 students ranked Spanish as being the most stressful language (S22, S24, S25, S27, S30, S32) and commented on the following: S22 claimed that she had troubled remembering verbs. She added that she knew what she wanted to say but had trouble with finding the right words. The student also stated that she did not think her high-school prepared students well - students did not feel a sense of belonging to the group. Moreover, she emphasized the fact that the Polish teachers of Spanish only helped those who were fascinated with the Hispanic world, and that the rest of the students were ignored. S24 said that the most stressful thing about Spanish was speaking with natives. She said that she was afraid of running out of words and that she had an intense fear of making mistakes. S27 felt that her vocabulary had become poorer (we believe that this was in part because of the little time she had to participate in a sixteen-people group). Her level was, however, quite high. S30 said that she was afraid of making mistakes and looking ridiculous. She said that she had attended a bilingual school, where she had both Spaniards and Poles as teachers and that 
the atmosphere among the Spanish (native) teachers was very positive because students felt they could talk openly about different issues, whereas the Polish teachers of Spanish did not let them make any jokes in class.

Other 6 students ranked Spanish as the second most stressful language (S18, S19, S20, S29, S31, S33) and stated the following: S19 said that grammar was the most stressful thing because she felt she was not "a very organized person"; S20 claimed that the most difficult thing for her was speaking, that she would always get nervous before speaking and her mind would go blank; S31 underlined the fact that he felt he could not express himself as he wanted because of a lack of words. He said he had attended a bilingual high school, where his Spanish teacher from Spain was good, but the Polish teachers of Spanish could not care less ("les daba todo igual”); S33 said she was afraid of not remembering verb conjugations and making mistakes ("at school, we were all afraid of making mistakes because the atmosphere with our Polish teacher was very negative"). She added that she had also had a native speaker as a teacher who provided a positive atmosphere in class. The rest of the students (S21, S23, S26, S34) commented the following: S23 said that speaking in a different language always stressed her out and she felt that her accent in Spanish was "just horrible" - which in fact was not true, she was one of the strongest students in the class. She had attended a bilingual school during her teenage years, where she had had five different teachers. She underlined the fact that when classes were taught by native speakers they were nice and "chaotic", while Polish teachers had, in her opinion, a terrible accent and a very pessimistic attitude. S26 said she found it difficult to speak, mainly because she had the impression of not speaking Spanish correctly and that she was in fact speaking "portuñol" (a mixture between Portuguese and Spanish) - indeed, both in terms of pronunciation and vocabulary, Portuguese seemed to have a big influence on her Spanish. She said she had also attended a bilingual school and that the atmosphere provided by the Polish teachers was a very severe one. S21 argued that grammar and tenses were the most difficult. At school, she had had both a Polish teacher (who "instilled fear among the students") and a native speaker ("positive guy"). Finally, S34 said that she did not quite understand how and when to use the subjunctive mood. She had also attended a bilingual school, where she had classes with a Polish teacher who "had her favorites", which was something that the rest of the students did not like at all.

\section{Discussion}

The survey was carried out in order to explore the students' background in terms of learning environment factors (e.g. De Angelis 2007; Gibson and Hufeisen 2011; Otwinowska 2016; Vildomec 1963), affective factors (e.g. Cenoz 2003; Dewaele 1998; Gibson and Hufeisen 2011), recency and frequency of use (e.g. Cheung et al. 2011; De Angelis 2007; Dewaele 1998), perceived linguistic distance (e.g. Corder 1983; Kellerman 1977; Odlin 1989; Otwinowska 2016; Otwinowska-Kasztelanic 2011; Ringbom 2007; Sanchez 2011; Singleton 1987, 2016), as well as multilingualism and language constellations background (e.g. Aronin and Singleton 2012; Cenoz 2003; De Angelis 2007; Jessner et al. 2016; Herdina and Jessner 2002; Mesthrie 2010; Otwinowska 2016; Vildomec 1963). All of 
these factors seem to play a decisive role in the learners' performance in their FLs and, in Dewaele's words (2010: 37): “there is growing acceptance within the SLA community that learners' feelings and reflections on their learning process, language use and changing identity offer valuable insights into aspects traditionally overlooked in SLA".

The fact that Spanish was chosen either as the most stressful or as the second most stressful language in both groups (B1 and B2) raised many questions because initially we had expected English to take that place, given its associations with work, obligations and the current emphasis on business English. At the beginning of this study, we were convinced that Spanish had very low levels of FLA among the students, since they probably associated it with holidays, leisure time, music, soap operas, etc. This is why the results were shocking and a follow-up session was very much needed in order to explore the reasons behind their choices. The data recollected during that session was also surprising: among the 31 students who decided to give feedback during the follow-up session, 12 of them (S4, S8, S11, S15, S21, S22, S23, S26, S30, S31, S33, and S34) pointed to their Polish teachers of Spanish as the source of their foreign language anxiety (FLA). On the other hand, they felt that the native Spanish speakers who had been their teachers had a more positive approach and encouraged them to participate actively in class. This drew our attention to the importance of the role of the teacher when it comes to language learning in formal settings. We feel that we should take notice of the impact teaching methods have, as well as setting a class atmosphere which encourages active participation if we do not want to hamper students' performance in the target language, since increased foreign language anxiety could act as a hurdle on their path to successful language learning.

Another interesting fact is that our results in terms of psychotypology do not seem to echo those of Otwinowska (2016), who, having posed the question Are Polish and English closely related?, reported: "it turned out that the vast majority of students (94-97\% in each group), with no regard to their knowledge of English and the number of languages known, did not perceive the two languages as closely related" (2016: 147). In our study, however, although English is nevertheless perceived as a distant language, an average of about $20 \%$ of the students seem to perceive some resemblance between English and Polish (see Table 4). Moreover, regarding her question: Which systems of English are easiest for a Pole to master: grammar, vocabulary, phonology? (2016: 148), over one third of all her students opted for vocabulary, while our B1 group also ranked grammar and morphology, along with vocabulary, and our B2 group ranked syntax first. Nevertheless, we should bear in mind that in our survey we did not formulate the question in the same way and, in fact, students had to choose among the languages they knew, which might lead to the difference in our results.

Finally, Otwinowska-Kasztelanic (2011: 12) found that "multilinguals strongly agreed that crosslinguistic similarities helped them with language learning (95\% positive answers) and strongly pointed to lexical similarities (64\%) as the most helpful. Interestingly enough, they did not see phonological similarities as relevant for language learning". This may suggest that, even though Spanish ranked first in terms of phonological similarities, this might not be perceived as a 
facilitator when it comes to learning Spanish. Our results seem to confirm this since the majority opted for English as being the most similar to Polish in terms of vocabulary, pointing out that they may fail to see lexical similarity between Polish and Spanish, despite their perception of phonetic similarity. This could be explained by more cumulative learning experience in the case of English, resulting in more awareness in terms of crosslinguistic similarity (cf. Otwinowska 2016). However, the fact that Polish was often ranked as the least prestigious language raises the question whether students may be able to make use of positive crosslinguistic information ${ }^{3}$ coming from their knowledge of Polish (it scored the highest in terms of proficiency and frequency of use, besides from being the students' L1) while learning Spanish.

\section{Methodological limitations}

It is important to acknowledge certain limitations regarding our research. First of all, and because our study was conducted among university students, we should bear in mind that there is clearly an over-representation of highly educated, female, polyglot participants and, therefore, the data resulting from this research might not reflect the situation of every single student of Spanish in Poland. Moreover, given the fact that this study deals with cross-sectional data, we are not able to see how the perceived linguistic distance (psychotypology) evolves from the very early stages to more advanced ones of Spanish learning. As far as we know, there is no study of this type to date.

\section{Acknowledgments}

The author would like to thank all the Polish students from the B1 and B2 Spanish courses who agreed to take part in the survey and without whom this study would have been impossible. Moreover, he would also like to thank Prof. Jacek Perlin for the inspiration provided during countless seminars and personal communications; Joanna Falgowska for her great help in the translation of the survey into Polish; and the anonymous reviewer of this article for comments and suggestions.

\section{References}

Aronin, Larissa and David Singleton. 2008. Multilingualism as a new linguistic dispensation. International Journal of Multilingualism 5(1). 1-16.

Aronin, Larissa and David Singleton. 2012. Multilingualism. Amsterdam and Philadelphia: John Benjamins.

Cenoz, Jasone. 2003. The role of typology in the organization of the multilingual lexicon. In: Jasone Cenoz, Britta Hufeisen \& Ulrike Jessner (eds.), The Multilingual Lexicon, 103-116. New York: Kluwer Academic Publishers.

Cheung, Anna S.C., Stephen Matthews and Wai Lan Tsang. 2011. Transfer from L3 German to L2 English in the domain of tense/aspect. In: Gessica De Angelis y Jean-Marc Dewaele (eds.),

3 For example, Spanish me gusta is structurally (though not exactly the same semantically) more similar to Polish podoba mi się than to English I like it. 
New Trends in Crosslinguistic Influence and Multilingualism Research, 53-73. Clevedon, UK: Multilingual Matters.

Corder, Stephen Pit. 1983. A role for the mother tongue. In: Susan Gass \& Larry Selinker (eds.), Language Transfer in Language Learning, 85-97. Rowley, MA: Newbury.

De Angelis, Gessica. 2007. Third or Additional Language Acquisition. Clevedon, UK: Multilingual Matters

Dewaele, Jean-Marc. 1998. Lexical inventions: French interlanguage as L2 versus L3. Applied Linguistics 19(4). 471-490.

Dewaele, Jean-Marc. 2010. Emotions in Multiple Languages. London: Palgrave Macmillan.

Gibson, Martha and Britta Hufeisen. 2011. Perception of preposition errors in semantically correct versus erroneous contexts by multilingual advanced English as a foreign language learners: measuring metalinguistic awareness. In: Gessica De Angelis and Jean-Marc Dewaele (eds.), New Trends in Crosslinguistic Influence and Multilingualism Research, 74-85. Clevedon, UK: Multilingual Matters.

Herdina, Philip and Ulrike Jessner. 2002. A Dynamic Model of Multilingualism: Perspectives of Change in Psycholinguistics. Clevedon: Multilingual Matters.

Hoffmann, Charlotte. 2000. The spread of English and the growth of multilingualism with English in Europe. In Cenoz, Jasone and Ulrike Jessner (eds.), English in Europe: The Acquisition of a Third Language, 1-21. Clevedon: Multilingual Matters.

Jessner, Ulrike. 2006. Linguistic Awareness in Multilinguals: English as a Third Language. Edinburgh: Edinburgh University Press.

Jessner, Ulrike, Manon Megens and Stefanie Graus. 2016. Crosslinguistic influence in third language acquisition. In: Rosa Alonso Alonso (ed.), Crosslinguistic influence in Second Language Acquisition, 193-214. Bristol: Multilingual Matters.

Kasper, Gabriele and Eric Kellerman (eds.). 1997. Communication Strategies: Psycholinguistic and Sociolinguistic Perspectives. New York: Longman.

Kellerman, Eric. 1977. Towards a characterisation of the strategy of transfer in second language learning. Interlanguage Studies Bulletin, 2(1), 58-145.

Kucharczyk, Radosław. 2018. Nauczanie języków obcych a dydaktyka wielojęzyczności (na przykładzie francuskiego jako drugiego jezzyka obcego). Lublin: Wydawnictwo Werset.

Larsen-Freeman, Diane and Michael Long. 1991. An Introduction to Second Language Acquisition Research. London: Longman.

Lewaszkiewicz, Tadeusz. 2015. Wpływ języka niemieckiego na system gramatyczny języka ogólnopolskiego (na tle wpływów innojęzycznych). In: Sonja Wölke and Hauke Bartels (eds.), Einflüsse des Deutschen auf die grammatische Struktur slawischer Sprachen, 90-120. Bautzen: Domowina-Verlag.

Mesthrie, Rajend. 2010. Sociolinguistics and sociology of language. In: Bernard Spolsky and Francis M. Hult (eds.), The Handbook of Educational Linguistics, 66-82. Singapore: WileyBlackwell. 
Mettewie, Laurence. 2004. Attitudes en motivate van taalleerders in België (Attitudes and motivation of language learners in Belgium), Unpublished PhD dissertation, Free University of Brussels.

Odlin, Terence. 1989. Language Transfer. Cambridge: CUP.

Otwinowska, Agnieszka. 2016. Cognate Vocabulary in Language Acquisition and Use. Attitudes, Awareness, Activation. Bristol: Multilingual Matters.

Otwinowska-Kasztelanic, Agnieszka. 2011. Awareness and affordances: multilingual versus bilinguals and their perceptions of cognates. In: Gessica De Angelis and Jean-Marc Dewaele (eds.), New Trends in Crosslinguistic Influence and Multilingualism Research, 1-18. Clevedon, UK: Multilingual Matters.

Poulisse, Nanda. 1997. Compensatory stategies and the principles of clarity and economy. In: Gabriele Kasper and Eric Kellerman (eds.),Communication Strategies: Psycholinguistic and Sociolinguistic Perspectives, 49-64. New York: Longman.

Ringbom, Håkan. 2007. Cross-linguistic Similarity in Foreign Language Learning. Clevedon: Multilingual Matters.

Sánchez, Laura. 2011. 'Luisa and Pedrito's dog will the breakfast eat': interlanguage transfer and the role of the second language factor". In: Gessica De Angelis and Jean-Marc Dewaele (eds.), New Trends in Crosslinguistic Influence and Multilingualism Research, 86-103. Clevedon, UK: Multilingual Matters.

Singleton, David. 1987. Mother and other tongue influences on learner French. Studies in Second Language Acquisition 9(3), 327-345.

Singleton, David. 2016. Cross-Lexical interaction and the structure of the mental lexicon. In: Liming Yu and Terence Odlin (eds.), New Perspectives on Transfer in Second Language Learning, 51-62. Bristol: Multilingual Matters.

Vildomec, Věroboj. 1963. Multilingualism. Netherlands: A.W. Sythoff-Leyden.

Wang, Meihua. 2015. A study on the relationship between age onset of English learning and English achievement. Theory and Practice in Language Studies, 1. 164-169. 


\section{APPENDIX}

\section{ANKIETA WSTĘPNA}

1. Wiek:

\section{Motywacja:}

a) Wewnętrzna (dla samego siebie):

b) Zewnętrzna (egzaminy, praca, itp.):

c) Wewnętrzna/Zewnętrzna:

\section{Miejsce urodzenia:}

\section{Doświadczenie lingwistyczne:}

Oceń języki, które znasz pod względem niżej wymienionych kryteriów:

4.1 Oceń, który język znasz najlepiej (5), a który najsłabiej (1).

\begin{tabular}{|l|l|l|l|l|}
\hline 5 & 4 & 3 & 2 & 1 \\
\hline & & & & \\
\hline
\end{tabular}

4.2 Z którym językiem identyfikujesz się najbardziej (5), a z którym najmniej (1)? Który język odzwierciedla Twoją osobowość?

\begin{tabular}{|l|l|l|l|l|}
\hline 5 & 4 & 3 & 2 & 1 \\
\hline & & & & \\
\hline
\end{tabular}

4.3 Który język jest najbardziej przydatny (5) do wyrażania Twoich emocji, potrzeb, strachu, a który jest najmniej przydatny (1)?

\begin{tabular}{|l|l|l|l|l|}
\hline 5 & 4 & 3 & 2 & 1 \\
\hline & & & & \\
\hline
\end{tabular}


4.4. Który język jest najbardziej przydatny (5) w komunikacji, a który najmniej (1)?

\begin{tabular}{|l|l|l|l|l|}
\hline 5 & 4 & 3 & 2 & 1 \\
\hline & & & & \\
\hline
\end{tabular}

4.5. W twojej opinii, który język jest najbardziej prestiżowy (5), a który najmniej (1)?

\begin{tabular}{|l|l|l|l|l|}
\hline 5 & 4 & 3 & 2 & 1 \\
\hline & & & & \\
\hline
\end{tabular}

4.6. Który język przysparza ci najwięcej stresu (5), a który najmniej (1)?

\begin{tabular}{|l|l|l|l|l|}
\hline 5 & 4 & 3 & 2 & 1 \\
\hline & & & & \\
\hline
\end{tabular}

4.7. Który język brzmi dla ciebie najprzyjemniej (5), a który najmniej przyjemnie (1)?

\begin{tabular}{|l|l|l|l|l|}
\hline 5 & 4 & 3 & 2 & 1 \\
\hline & & & & \\
\hline
\end{tabular}

4.8. Którego języka używasz najczęściej (5), a którego najrzadziej (1)?

\begin{tabular}{|l|l|l|l|l|}
\hline 5 & 4 & 3 & 2 & 1 \\
\hline & & & & \\
\hline
\end{tabular}

4.9. W jakim wieku zacząłeś/aś uczyć się tych języków, które znasz?

\begin{tabular}{|l|l|l|l|l|}
\hline 5 & 4 & 3 & 2 & 1 \\
\hline & & & & \\
\hline
\end{tabular}

5. Typ i ilość ekspozycji na język docelowy:

\subsection{Hiszpański:}

\subsubsection{Typ nauki:}

5.1.2 Czas nauki:

5.1.3 Częstość używania języka: 
5.1.4 Czy kiedykolwiek byłeś/aś w krajach hiszpańskojęzycznych?:

5.1.5 Czy masz przyjaciół/rodzinę hiszpańskojęzycznych?:

\subsection{Angielski:}

\subsubsection{Typ nauki:}

\subsubsection{Czas nauki:}

5.2.3 Częstość używania języka:

5.2.4 Czy kiedykolwiek byłeś/aś w krajach anglojęzycznych?:

5.2.5 Czy masz przyjaciół/rodzinę anglojęzycznych?:

5.3 (W przypadku jeśli angielski nie jest Twoim drugim językiem):

\subsubsection{Typ nauki:}

\subsubsection{Czas nauki:}

\subsubsection{Częstość używania języka:}

5.3.4 Czy kiedykolwiek byłeś/aś w krajach, gdzie używa się tego języka?:

5.3.5 Czy masz przyjaciół/rodzinę, którzy używają tego języka?:

6. Dystans lingwistyczny:

6.1. Z języków, których używasz, który jest najbardziej zbliżony do języka polskiego?

\begin{tabular}{|l|l|}
\hline W słownictwie: & \\
\hline W fonetyce: & \\
\hline W gramatyce: & \\
\hline W składni: & \\
\hline
\end{tabular}


W morfologii

(w słowotwórstwie):

6.2 Który język - angielski czy polski - pomaga ci bardziej w nauce hiszpańskiego?

\begin{tabular}{|l|l|}
\hline W słownictwie: & \\
\hline W fonetyce: & \\
\hline W gramatyce: & \\
\hline W składni: & \\
\hline $\begin{array}{l}\text { W morfologii } \\
\text { (w słowotwórstwie): }\end{array}$ & \\
\hline
\end{tabular}

